\title{
ヒメシロチョウ成虫の活動空間の整備に関する研究
}

\section{A Study of the Improvement of the Spacial Condition to Inhabit the Butterfly, Lapidea amurensis}

中尾史郎 ${ }^{*}$ 中島敦司 ${ }^{*}$ 養父志乃夫* 山田宏之* 鈴木武彦** 小松正明*** Shiro NAKAO Atsushi NAKASHIMA Shinobu YABU Hiroyuki YAMADA Takehiko SUZUKI Masaaki KOMATSU

\begin{abstract}
摘要：本研究では，ヒメシロチョウ成虫の活動空間の整備に寄与する基礎的な知見を得る目的で，成 虫の個体密度とその時の環境条件との関係性について検討した。その結果，調査を実施した春季には， 本種成虫は暗い樹林よりも明るく開放的な草地で多く確認され，特に吸蜜植物が高密度で開花してい る条件下に集中した。しかし，このような花の多い条件下でも，微風状態から風が強くなると確認さ れる成虫数が減少した。以上の結果, ヒメシロチョウ成虫の活動空間の整備のためには, 開放的な草 地，高密度の吸蜜植物、微風環境の 3 点の同時的な整備が重要であることが明らかとなった。
\end{abstract}

\section{1.はじめに}

近年，身近な自然を保全する気運の高まりとともに，各所でビ オトープの整備やミチゲーション，生態環境の保全を目的とした

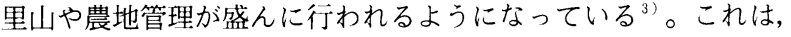
減少傾向にある生物種のなかには，農作業などの人為的な攬乱に 依存してきた種が少なくないことに起因している。そして，これ らの種が普通に見られる景観の保全，創造に対しては，積極的か つ持続的な人為管理が重要であると考えられるようになってき た ${ }^{4)}$ 。のような人為管理は, トータルとして自然環境の保全に 寄与するため，その指針の獲得を目指した研究が多く求められて いる。そして，そのような研究を統合化し，かっては普通にみら れた自然を守っていくことは重要な課題である。

このような背景の中，造園の役割と生きものの生息する景観や 環境整備の関連について議論されている。同時に，生きものの生 息する景観を創造するためには八ビタットの構造を生物種別に明 かにし，そのような生物学的知見を造園技術に反映させる必要の あることも指摘されている2)。

そのため本論では, 身近な生きものとしてチョウを取り上げ, なかでもヒメシロチョウLeptidea amurensisの成虫の活動空間 の整備に係る技術指針の獲得を目指し，環境条件之成虫の飛翔， 吸蜜などを含む個体密度の関係について検討した。そして，多く の成虫が活動するために必要な環境条件のいくつかを明らかにし たので，結果を報告する。

本研究でヒメシロチョウを取り上げた理由は，1）昆虫採集の ターゲットとされることの多い「チョウ」であること，2）可粼 で人里周辺にも生息している種であること， 3 ）農薬の使用や宅 地造成によって著しく個体数を減じたところが多い種であること， による1”。

\section{2、材料および方法}

(1) ヒメシロチョウについて

ヒメシロチョウLeptidea amurensisの特性について既存の資 料1) から整理すると，本種は中国大陸および日本に生息する旧北 区系の草原分布型のチョウであり，シロチョウ科の中で最も原始 的な系統に属する。日本においては，北海道，本州および九州に おいて局所的に分布し, 日当たりの良い山地の草地, 平地水田, 果樹園, 畑の周辺地, 畔などで見られる。一方, 本種の個体数お
よび生息地の減少が危惧されており，その保護および生息環境の 保全が望まれている。

本種は, 日本では年 $2 \sim 3$ 回発生する多化性の種であり, 春, 夏，秋という季節の経過とともに発生する成虫数は減少する。本 州の野外における確実な食草はツルフジバカマのみであるが，他 のマメ科草本との関連についてはよく分かっていない。吸蜜植物 については，普通に自生している草本であることが多いことに加 え紫色系の花を好む習性が強いことが知られている。

\section{(2) 調查地点}

現地調查は，1999 年 4 月に長野県安昙郡堀金村の標高 690 $700 \mathrm{~m}$ の扇状地面で実施した。

調查地点は, 1997 年には樹高 $2 \mathrm{~m}$ 以下のク , 樹高 $2 \sim 3 \mathrm{~m}$ のタチヤナギ，ヤマネコヤナギ，ヒメヤシャブシ， シラカンバに 加え，ススキやクズが密生するブッシュであった。調査に先立ち, 1998 年 3 月 10 日〜21 日に灌木林の一部を伐採し, 広さ $1,370 \mathrm{~m}^{2}$

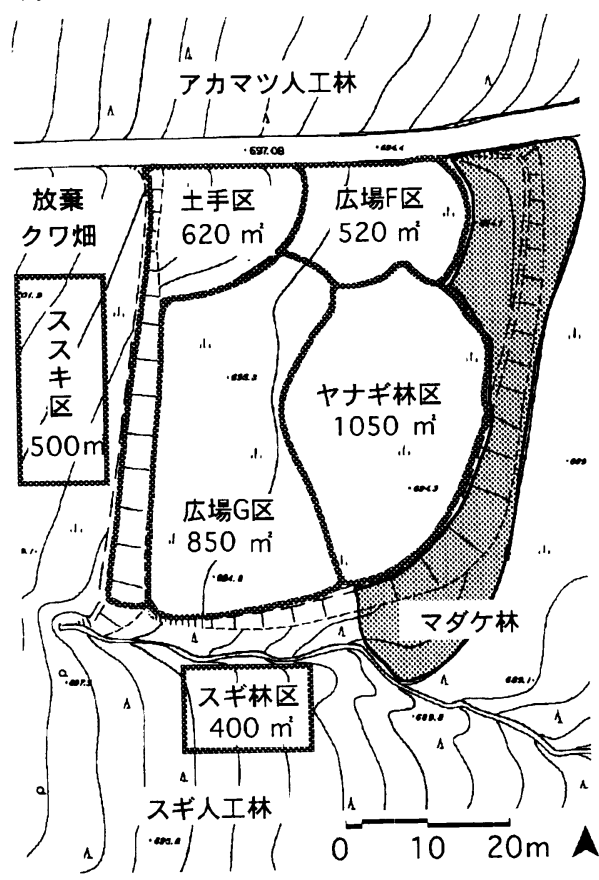

図-1＼cjkstart調査区の位置と面積

\footnotetext{
“和歌山大学システム工学部 “”建設省国営アルプスあづみの公園工事事務所 “*”建設省国営滝野すずらん丘陵公園工事事務所
} 

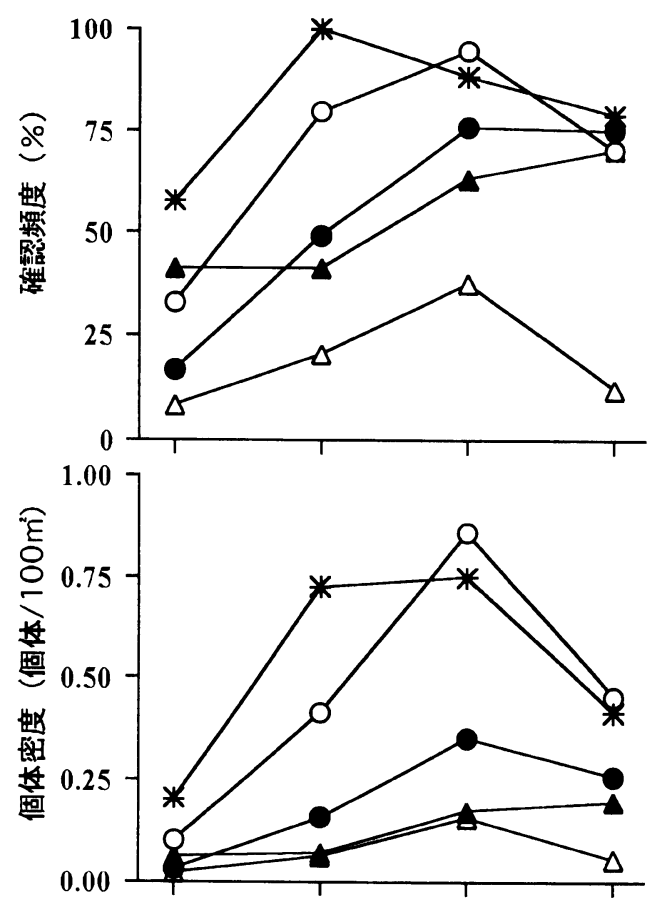

08:00-10:00 10:00-12:00 12:00-14:00 14:00-16:00 時間帯

図ー2 時間帯別, 区別にみたヒメシロチョウ成虫の確 認頻度（上図）と個体密度（下図）(1999 年 4 月 15 日〜17 日の平均, 長野県堀金村)

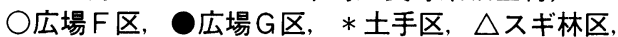
ムヤナギ林区

確認頻度は， 1 調查機会（5 分間）に 1 個体でも確 認された場合の頻度の各時間帯 24 回の調査機会に 対する場合

の開放的な広場（以下広場区とする）と広場区に隣接した広さ $620 \mathrm{~m}^{2}$ の土手部（以下土手区とする）を整備した。残りの広さ $1,050 \mathrm{~m}^{2}$ の範讲については，立木を間伐するとともにススキなど を刈り払い，樹高 $2 \sim 3 \mathrm{~m}$ の夕チヤナギを中心とした灌木林（以 下ヤナギ林区とする）となるように植生を調整した（図 1 )。

さらに，同期間に調查地点から約 $200 \mathrm{~m}$ 離れた位置にある放菓 畑の表土を運搬し， $15 \mathrm{~cm}$ の厚さで均一に敷きならした。その上で， 吸蜜植物の粗密を形成するために, 同放棄畑内で認められたカキ ドオシ群落を縦 $60 \mathrm{~cm}$, 横 $30 \mathrm{~cm}$, 厚さ $5 \mathrm{~cm}$ の大きさで土袞ごとは ぎ取り, 植生盤の状態で広場区の外周及びヤナギ林区の林床に 1 $\mathrm{m}^{2}$ 当たり 1 枚程度敷き並べた。その後, 広場区およびャナギ林区 では, 1998 年 7 月 14 日と 9 月 24 日に下刚りを実施し，地表面 がススキやクズで覆われないように植生管理した。

また調査は，上記の広場に隣接する樹高 $10 \mathrm{~m}$ を上回るスギ人 工林内（以下スギ林区とする）でも実施した。当林分の林齢は 40 年程度であったが，長期間にわたって放置されていたため，調査 前々年の 1997 年 7 月の時点では林床にほとんど植生を有しない 極めて暗い林分であった。このため，1997年8月に間伐を実施 し，その後は太陽光の入り込む林分となった。また 1998 年 4 月 には，林縁部の幅 $2 \mathrm{~m}$ にわたって前述のカキドオシの植生盤を 1 $\mathrm{m}^{2}$ 当たり 1 枚敷き並べた。

本調査において確認されたヒメシロチョウの個体であるが, 調 查地点では前年に食草となるッルフジバカマが生育していなかっ たことから, 他所で発生した個体が飛来してきたものと考えられ

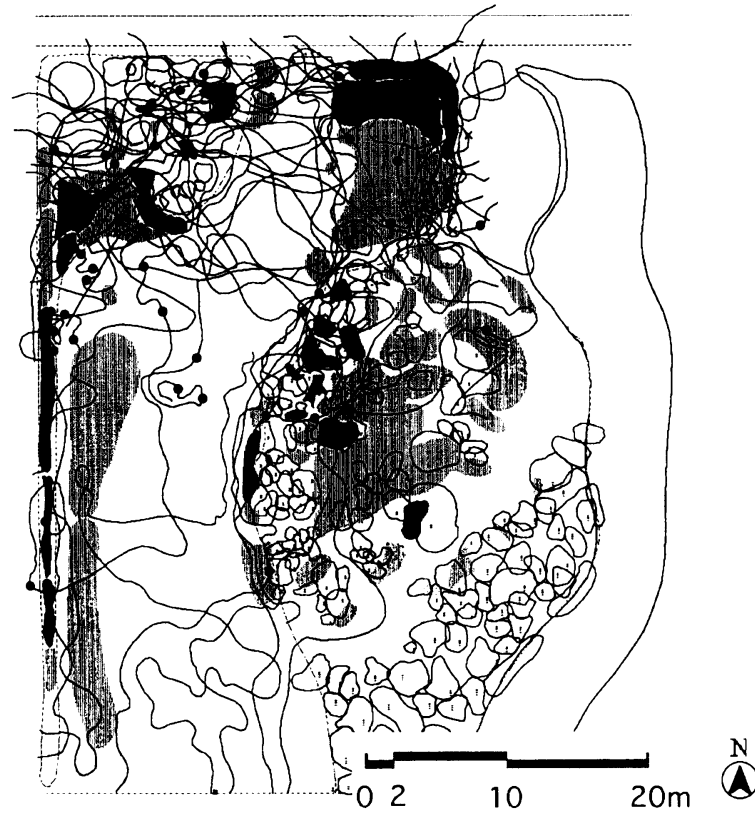

図ー3 ヒメシロチョウの飛翔・吸蜜と吸蜜植物の開花位置との 関係（1999 年 4 月 17 日 10:00 14:00, 長野県堀金村） 成虫の飛翔コース (太線), 吸蜜位置 (○), 樹冠 (細線), 吸蜜植物（花の被覆率 10\%未満は薄い灰色，26\%以上は濃 (灰色，11〜25\%はその中間色で表示)

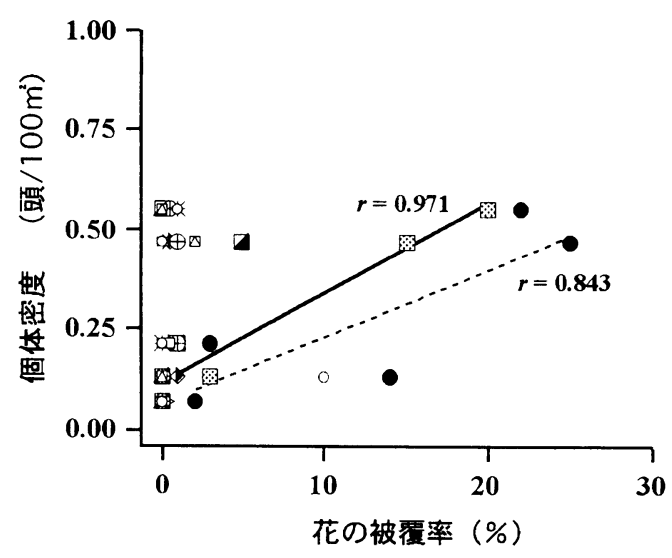

図一4 草種別にみた花の被覆率とヒメシロチョウ成虫の個体密 度の関係（1999年 4 月 15 日〜17日, $8: 00 \sim 16: 00$ の平均, 長野県堀金村)

注 : ススキ区は除く

○全草種合計(--・) ロヒメオドリソウ(一),

○カキドオシ， \ホトケノザ, ロタチイヌノフグリ, ○コナ

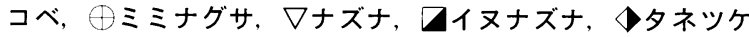
バナ, *タチツボスミレ, ヒカゲスミレ

た。発生地としての可能性があったのは，調査前年及び当年の夏 季にツルフジバカマが散見された調査地点に隣接する放裹クワ畑 内のススキ草地であった（以下，ススキ区とする）。ここは，調 査前年には樹高 $2 \mathrm{~m}$ 以下のクワに加えススキやクズが密生する群 落高 $2 \mathrm{~m}$ 上回るブッシュであった。調査を実施した 1999 年 4 月にはススキなどは生育開始していなかったため, 密生状態の草 地ではなかったが, 前年の枯死茎葉が地表面を被い，吸蜜植物之 なりえる草花は散見される程度であった。

\section{(3) 調查方法}

ヒメシロチョウ成虫の活動状況の調查は 1999 年 4 月 15 日〜17 
日の間に実施した。この間の天候は概ね薄い雲が認められる程度 の晴天であった。

調査項目は，環境条件としてススキ区を除く各区の光量子束密 度, 紫外線強度, 気温, 空中湿度, 風速の各気像条件に加え, 吸 蜜植物となりえるカキドオシ，ヒメオドリコソウ，ヒカゲスミレ， タチッボスミレ，タチイヌノフグリの植被率及び地面に対する花 の被覆率の各項目とした。さらに, 調相地点の樹冠投影図とと屯 に吸蜜植物の分布図を作成した。なお, 上記の光量子束密度は小 糸工業社製の MES-101 を，気温および空中湿度はT \& D 社製お んよ゙とり RH を用い，いずれも 1 分間隔で計測した。また，紫 外線強度は東レテクノ社製 SUV3000を，風速は EMPEX 社製 のWIND MESSE を用い，いずれも5 分間隔で計测した。

一方，ヒメシロチョウの成虫については, 広場区, 土手区, ヤ ナギ林区，スギ林区，ススキ区のそれぞれにおいて，8：00〜16： 00 の間の各 5 分間に日視で確認された成虫の個体数を記録し, 各区の面積にしたがって $100 \mathrm{~m}^{2}$ 当たりの個体密度を求めた。なお, 広場区については, 植生の違いにより, 吸蜜植物の多い筒所（広 場 F区)，少ない筒所（広場G区）に区分して個体数を記録した 他，ススキ区では群落頂部で確認できた個体数のみを記録した。 さらに, 10:00〜14:00に㧍ける成虫の飛翔コース, 吸蜜位置 を前述の植生図に記入した。

\section{3. 結果及び考察}

\section{（1）植生と成虫の飛翔の関係}

表 1 に示したように，開放空間の広場区と土手区にはカキドオ シやヒメオドリコソウなど成虫の吸蜜植物となる草花が開花し, 中でも広場 $\mathrm{F}$ 区，土手区では全体の $15 \%$ 以上の面積が花で被わ れていた。灌木林のヤナギ林区の林床でもカキドオシ, ヒメオド リコソウが開花しており，それぞれの花の被覆率は $10 \%$ と $3 \%$ であった。樹高 $10 \mathrm{~m}$ を回るスギ人工林のスギ林区の林床には, タチツボスミレやヒカゲスミレが生育, 開花していたが合計で 2 \%の花の被覆率に止まった。ススキ区では, エゾタンポポとヒメ オドリコソウが開花していたが, その花の被覆率は小であった。

表 1 から各区別の個体密度をみると, 開放的な広場 $\mathrm{F}$ 区, 広場 G区，土手区での個体密度は，樹林のヤナギ林区，スギ林区より も大であった。一方, 成虫を確認する調查は 5 分間隔で実施した が, 図2に8:00〜16:00を2 時間単位で区切って, それぞれの

表 -1 場所別の花の被覆率 “と調査区別のヒメシロチョウ成虫の個体密度”*

\begin{tabular}{|c|c|c|c|c|c|c|}
\hline & 広場F区 & 広場 G区 & 土手区 & ヤナギ林区 & スギ林区 & ススキ区 \\
\hline 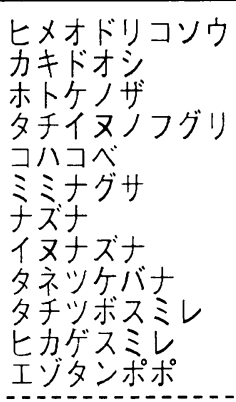 & $\begin{array}{cc}15 \% & (60 \%)^{* * *} \\
- & - \\
2 & 3 \\
2 & 3 \\
1 & 3 \\
1 & 3 \\
5 & 3 \\
+ & 10 \\
+ & 1 \\
- & 1 \\
- & - \\
+ & - \\
+\end{array}$ & 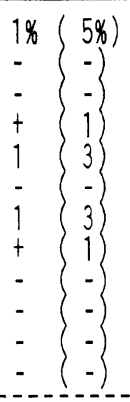 & $\begin{array}{c}20 \% \\
1 \\
- \\
- \\
- \\
+ \\
- \\
- \\
- \\
- \\
+ \\
1 \\
1 \\
- \\
- \\
- \\
+ \\
+ \\
- \\
-\end{array}$ & $\begin{array}{c}3 \% \\
10 \\
- \\
- \\
- \\
- \\
- \\
- \\
- \\
1 \\
- \\
- \\
- \\
- \\
- \\
+ \\
+ \\
- \\
- \\
- \\
-\end{array}$ & 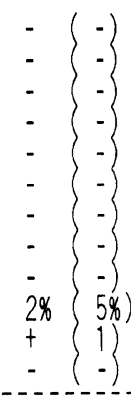 & $\begin{array}{l}1 \% \\
- \\
- \\
- \\
- \\
- \\
- \\
- \\
- \\
- \\
- \\
- \\
- \\
+\end{array}-3=$ \\
\hline 計 & $25 \quad(60)$ & $3(5)$ & $22 \quad(50)$ & $14 \quad(50)$ & $2(5)$ & $1(3)$ \\
\hline 成虫の個体密度 & $0.47 \mathrm{a}$ & $0.21 \mathrm{~b}$ & $0.55 \mathrm{a}$ & $0.13 \mathrm{c}$ & $0.07 \mathrm{~d}$ & $0.08 d$ \\
\hline
\end{tabular}

* : : 花の被覆率は地面に対する花の被覆面積の割合

**: : $100 \mathrm{~m}^{2}$ 当たりに換算した数值（1999年 4 月15日〜17日,8:00〜16:00の平均)

$* * *$ （）内の\%は㮔別の群落における花の被覆率の最大值

成虫の個体密度に付記した $\mathrm{a} \sim \mathrm{d}$ は $\mathrm{t}$ 検定の結果による（ $p \leqq 0.05 ）$

ススキ区における成虫の個体密度は群落頂部での結果
時間帯，調査区別に成虫が確認された調査 5 分間の頻度を示した。

これによると，スギ林区では他の区よりも確認される割合の低 いことが分かる。また，広場 $\mathrm{F}$ 区，土手区では，10：00 以降に， 広場 $\mathrm{G}$ 区, ヤナギ林区では 12:00 以降の時間帯に, それぞれ成 虫が確認された頻度は大となった。さらに, 場所帯別の個体密度 は, 広場 $\mathrm{F}$ 区之土手区で大きく、これらよりもスギ林区とヤナギ 林区で小となった。次に, 時間帯別の個体密度をみると, ヤナギ 林区を除き, $12: 00 \sim 14: 00$ の時間帯に個体密度が大きく, 土手 区では 10：00〜12：00 の時間帯でも個体密度が大となった。し

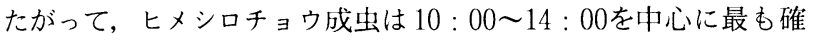
認され，樹林よりも開放地で個体密度が大きくなると考えられた。

図 3 に, 多くの成虫が確認された広場 $\mathrm{F}$ 区, 上手区とそれらに 隣接する広場 G区とヤナギ林区に㧍ける 4 月 17 日 10：00〜14： 00 の吸蜜植物の開花状況之成虫の飛翔コースを示した。これを みると, 成虫は広場 $\mathrm{F}$ 区や土手区で花の被覆率が $26 \%$ を回る 箇所あるいはそれらの付近を中心に飛翔, 吸蜜していたことが明 らかである。ヤナギ林区においては林床を中心に成虫の活動が認 められたが，ここでも成虫は花の被覆率が 26\%を上回る筬所あ るいはそれらの付近を中心に飛翔していた。

そこで, 花の被覆率之個体密度の関係を検討すると（図 4), 花の被覆率が高くなるにしたがって成虫の個体密度も高くなる傾 向が認められた。特に, スギ林区以外で開花し, 花の被覆率の高 かったヒメオドリコソウでは上記傾向が強くなった。なお，他の 草種では花の被覆率が高くなく，しかも全域で開花していないこ とから上記傾向は検討できなかった。しかし, 本種が紫色系の花 を好む”ことから，カキドオシやタチッボスミレなどの紫色系の 花を開花させる種でも, 花の被覆率が高くなればヒメオドリコソ ウと同様の傾向が認められるものと推察される。いずれにせよ, 調查地点ではヒメオドリコソウを主体とした吸蜜植物の開花密度 と成虫の活動との間には対応関係が認められた。

一方，管理をおこなわず放置状態にあったススキ区は，広場区， 土手区と同様に草地ではあったが，成虫の個体密度は広場区，土 手区よりあ小であった（表 1)。このことは, 吸蜜植物となる花 の被覆率が小であったことの影響と考えられたが, 群落の空間構 造の違いもあり, 今後の課題である。

以上の結果，ヒメシロチョウ成虫の活動空間の整備のためには, 開放的な空間, 吸蜜植物が高密度で開花していることの双方を整 備する必要があると考えられ た。

（2）気象条件亡成虫の飛翔・ 滞留の関係

図 5 に, $8: 00 \sim 16: 00$ を2 時間単位で区切った時間 帯別の成虫の 5 分間の $100 \mathrm{~m}^{2}$ 当たりの個体密度と, 光量子 束密度, 紫外線強度, 気温, 空中湿度, 風速との関係を示 した。これによると, 成虫の 個体密度といずれの環境条件 との間には強い相関は認めら れず，時間帯別にみても同様 であった。これは, ある条件 に達すれば成虫が必ず確認さ れるというわけではないこと を示している。しかし，いず れの時間帯においても, 個体 密度 1.25 個体 $/ 100 \mathrm{~m}^{2}$ を回っ た条件は，概ねその時間帯の 


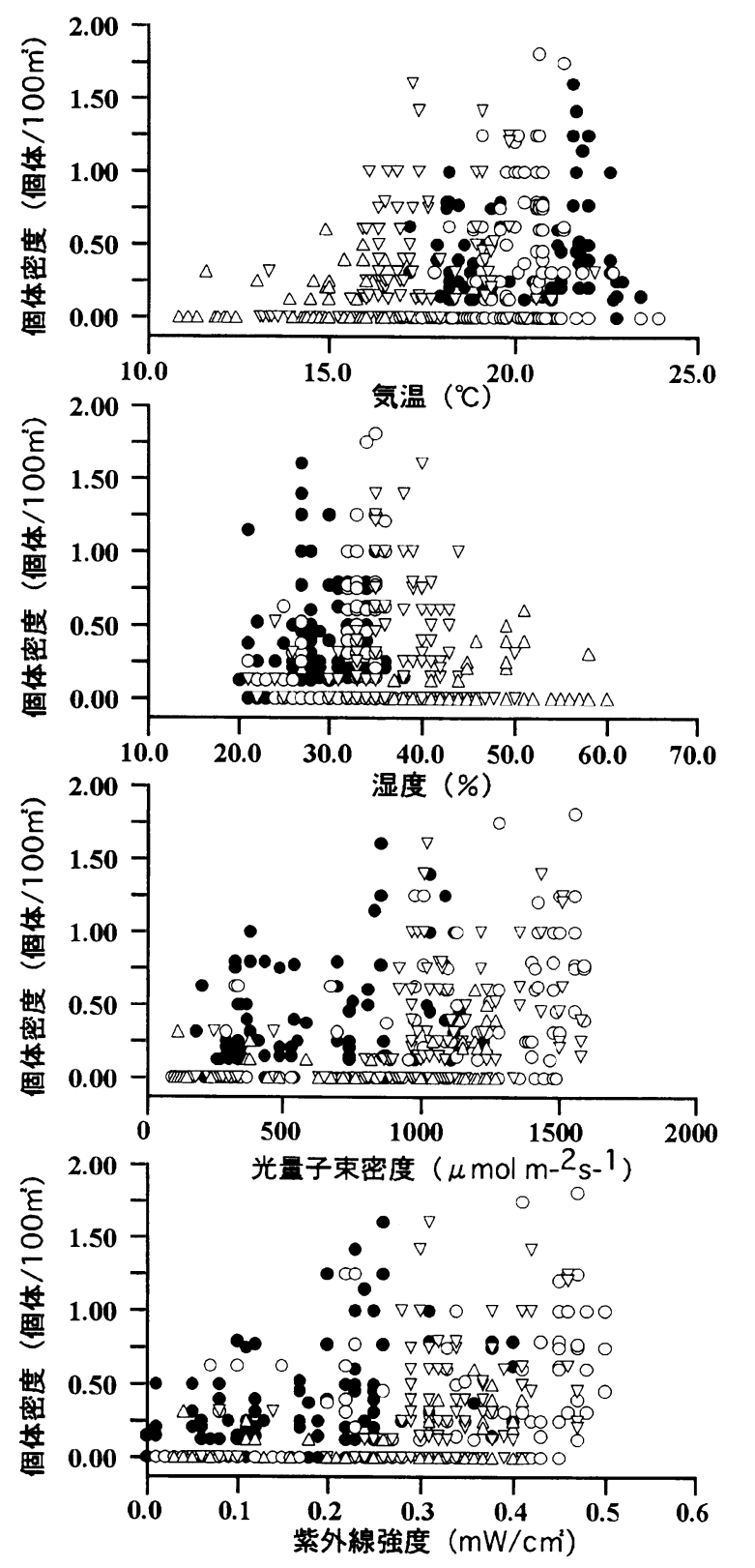

図ー5 時間帯にみた気象条件とヒメシロチョウ成虫の個体密度 の関係（1999年 4 月 15 日 17 日, 長野県堀金村）

$\triangle 8: 00-10: 00, \nabla 10: 00-12: 00,012: 00-14: 00$,

$14: 00-16: 00$

中で光量子束密度や紫外線強度の值が大となるような明るく，あ るいは気温の高い条件下であった。

そこで, 最も成虫が多く確認された広場 $\mathrm{F}$ 区および土手区につ

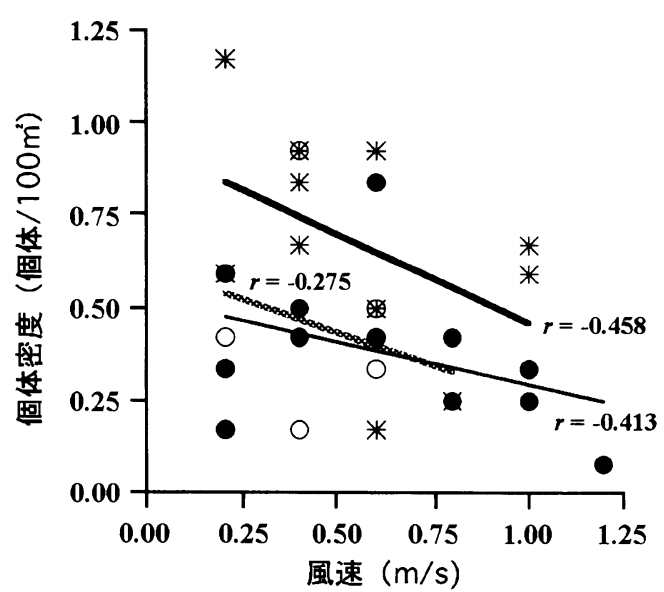

図－6 光量子束密度別にみた風速とヒメシロチョウ成虫の個体 密度の関係（1999 年 4 月 17 日 $10: 00 \sim 14: 00$, 長野県 堀金村)

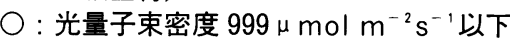

: 光量子束密度 $1000 \sim 1249 \mu \mathrm{mol} \mathrm{m}{ }^{-2} \mathrm{~s}^{-1}$

* : 光量子束密度 $1250 \mu \mathrm{mol} \mathrm{m}{ }^{-2} \mathrm{~s}^{-1}$ 以上

いて（表 1)，4月 17 日 $10 ： 00 \sim 14 ： 00$ における風速と 5 分間 の $100 \mathrm{~m}^{2}$ 当たりの個体密度との相関を同程度の光量子束密度別に 整理した（図 6 )。これによると, いずれの光量子束密度の条件 下においても, 風速が強くなるほど個体密度が低下する傾向が認 められた。しかも，そのような傾向が風速 $1.5 \mathrm{~m}$ に満たない微風 条件下においてみられたという結果は, 本種の成虫の活動が風の 影響を受けやすいことを示すものである。

したがって, 本種の成虫の活動空間の整備のためは, 開放的な 草地, 吸蜜植物が高密度で開花していることに加え, 微風環境亡 なる条件を整備することが重要と考えられた。また, 草地の周辺 に防風林を整備し, 微風環境亡なるように条件整備することによっ て成虫の滞留を促すことも可能と考えられた。

\section{4.おわりに}

本研究を実施した結果, ヒメシロチョウ成虫の活動空間の整備 のためには開放的な草地で, 吸蜜植物が高密度で開花しているこ とに加え，微風環境となる条件の整備が重要であると考えられた。

一方, 放置されたブッシュのススキ区では明るい群落頂部にお いても成虫の個体密度は小であった。したがって，広場区や土手 区で多くのヒメシロチョウが確認されたことは, 1997年から継続し てきた間伐, 下刚り, 植生盤設置等の一連の植生管理によって開 放的で吸蜜植物が高密度で開花する環境条件を整備した結果の可 能性がある。しかし, 生息地の保全という視点からは成虫の活動空 間の整備だけでは不足である。このため今後は, 本論の結果を活 用し，生息地の保全を目指した統合的な研究の実施が重要である。
引用文献

1) 福田晴夫他（1982）：原色日本蝶類生 態図鑑（I ）: 保育社, $131-135$

2 ）倉本宣・春田章博・小野三津子 (1999):
生態工学の技術観：ランドスケープ研 究 $62(4), 370-377$

3 ) 杉山恵一・福留脩文 (1999) : ビオトー プの構造 : 朝倉書店, pp181
4）杉山恵一・進士五十八（1992）：自然 環境復元の技術 : 朝倉書店, pp170

Summary : We investigated the relationships between the density of Lapidea amurensis adults and several environmental conditions in order to obtain the fundamental knowledges for the improvement of the condition that high density of adults can be active. As the result, the density of adults at the open grass field were large in comparison with the forest inside in spring. And the density of adults were large under the conditions with many flowers blooming. However, the density of adults decreased under the windy conditions. So it is considered that preparing the sunny and windless grass field with many flowers blooming is necessary for the improvement of the condition that many adults can be active. 